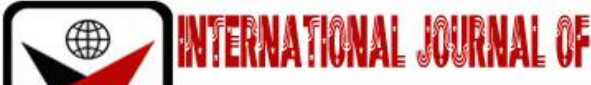

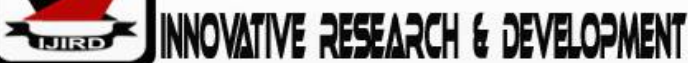

ISSN 2278 - 0211 (Online)

\section{Innovation Activities, Business Networks and Firm Performance: Review Article}

\author{
Zenebech Admasu Gebreamilack \\ Ph.D. Student, School of Economics, Shanghai University, China
}

\begin{abstract}
:
Innovation is generally regarded as a critical success factor in sustaining growth and competitiveness of firms in domestic and global markets. In response to this demanding competition, firms put innovation strategy and find way to diffuse effective innovations using their business network. The importance of network activities for innovation diffusion and innovation research has been recognized only recently. Besides, the use social network analysis as a research tool also becomes a novel exercise. This review aims at highlighting the importance of innovation to firms, the role of network activities in firm innovation, and the use of social network analysis techniques in firm innovation analysis. Lastly, review of some empirical evidences relating innovation activities to firms' performance.
\end{abstract}

Keywords: Innovation, business networks, firms

\section{Introduction}

In today's globalized business environment, world firms are in competition to sustain profitability in the market and meeting customers' needs. They are in recurrent process to introduce new product and service, improve the existing; and innovation in firms also contributed to the rise in living standards in today's world (Greenstone, M. and Looney, A., 2011; OECD, 2007). It has been in a continuous process since the industrial revolution and today; indeed, innovation is a crucial factor in determining nations' competitiveness and national progress (OECD, 2007). According to World Economic Forum (WEF) Global Competitiveness Index, competitiveness is defined as the set of institutions, policies and factors that determine the level of productivity of a country; and a nation's competitiveness depends on the capacity of its industry to innovate and upgrade (Porter, M.E., 1990).

Hence, to respond successfully to a rapidly changing market conditions, pressures from competition, timely conquer the challenges and remain competitive in global economic environment; firms need to develop a range of export capabilities by accessing the state of art of new technologies, managerial practices, and technical and marketing skills; and continuously upgrade them over time. Entrepreneurship innovation is thus important element as ideas are transformed in to more productive economic activity (OECD, 2007) and a means for firms to differentiate from their competitors (Karlsson, C. and Tavassoli, S., 2015). Firms respond challenges of globalization in their own way; for instance, manufacturing firms in Europe concentrated and form the economic and monetary union as newly developing market economies in Eastern Europe start to emerge (Fischer, M. M., 1999).

Principally, firms need to engage in innovation activities and also interact with other actors in innovation ecosystem. Investing in new product development help firms to survive and gain competitive advantage (Gonzalez-Z., et al., 2017) and successful innovation help firms in building competitive advantage specially if it is based on anticipated customer needs (Porter, M. E., 1990) and successful innovators become leader in the market as it offer them cost or/and quality advantage and thereby make them more profitable (Marshall, G. and Parra, A., 2019). Firms also connect to the external sources of knowledge and create strategic alliances that reinforce their competitive position.

Thus, innovation is essential factor for firm survival, economic growth and development; and innovation strategy is an important major driver of firm performance and should be developed and executed as an integral part of the business strategy (Gunday, G. et al, 2011). Firms usually seen spending on Research and Development (R and D), acquire resources related to innovation. They also set innovation strategies to collaborate in innovation practices. Recently, researchers use social network analysis in innovation research.

\subsection{Concepts in Innovation}

Based on Oslo Manual (2018), an innovation ${ }^{1}$ is defined as: 'A new or improved product or process (combination of thereof) that differs significantly from the unit's previous products or processes and that has been made available to

${ }^{1}$ Innovation can be manifested in a new product design, a new production process, a new marketing approach, or a new way of conducting training (Michael E. Porter, 1990). And according to Oslo manual (OECD/ Eurostat, 2005) innovation could be product innovation, process innovation, marketing innovation and organizational innovation. 
potential users (product) or brought in to use by the unit (process)', (OECD/Eurostat, 2018). Further, Innovation activities are defined as 'all developmental, financial and commercial activities undertaken by a firm that are intended to result in an innovation for the firm', (OECD/Eurostat, 2018). Innovation activities according to Oslo Manual (2018) include Research and experimental Development (R and D) activities; engineering, design and creative activities; marketing and brand equity activities, IP related activities, employee training activities, software development and data base activities, activities related to acquisition of tangible assets, innovation management activities(OECD/Eurostat, 2018).

\subsection{The Innovation Ecosystem and Networks}

Innovation decisions are essential element for firm survival, economic growth and development; hence, firms develop innovation strategy. Innovation efforts without an innovation strategy are a mere waste of resource and cause misalignments among organs of an organization where they couldn't able to clarify objectives and priorities; hence, may cause conflict of priorities (Pisano, G., 2015). Thus, innovation strategy is an important major driver of firm performance and should be developed and executed as an integral part of the business strategy (Gunday, G. et al, 2011). One of strategy is firms desire to interact and collaborate with other actors in innovation ecosystem within and beyond the territory of innovating firm.

\subsection{Innovation Ecosystem}

Innovation ecosystem is the internal and external environment in which the innovators innovating on and interact with which broadly includes resources such as materials, human and the institutional entities embraces these resources. Ecosystems are networks comprise actors of diverse profiles (Adner, R. and Kapoor, R., 2016) and actors include firms, individuals, institutions, communities, individuals, state-supported researches (Adner, R. and Feiler, D., 2019) where innovative firms are the center of innovation system (Eggink M., 2013). An efficient innovation system should have technologically advanced individual actors that possess economic and social capabilities; strong institutions that provide a full range of services and legal basis that support economic and innovative activities; open, flexible and dynamic social networks that generate trust, cooperation, facilitate knowledge flows and support entrepreneurial activities (Agapitova, N., 2005).

The external environments in which the firms operate is an important factor and affect firms' innovation activities. The external environments are those factors out of firm's immediate control and they pose challenges or create opportunities to the firm thus firms deals with them strategically (OECD/Eurostat, 2018) which include the spatial factor, resource markets, public policy, knowledge flow and networks, social and natural environment. Figure 1 presents the external environment that can influence business innovation.

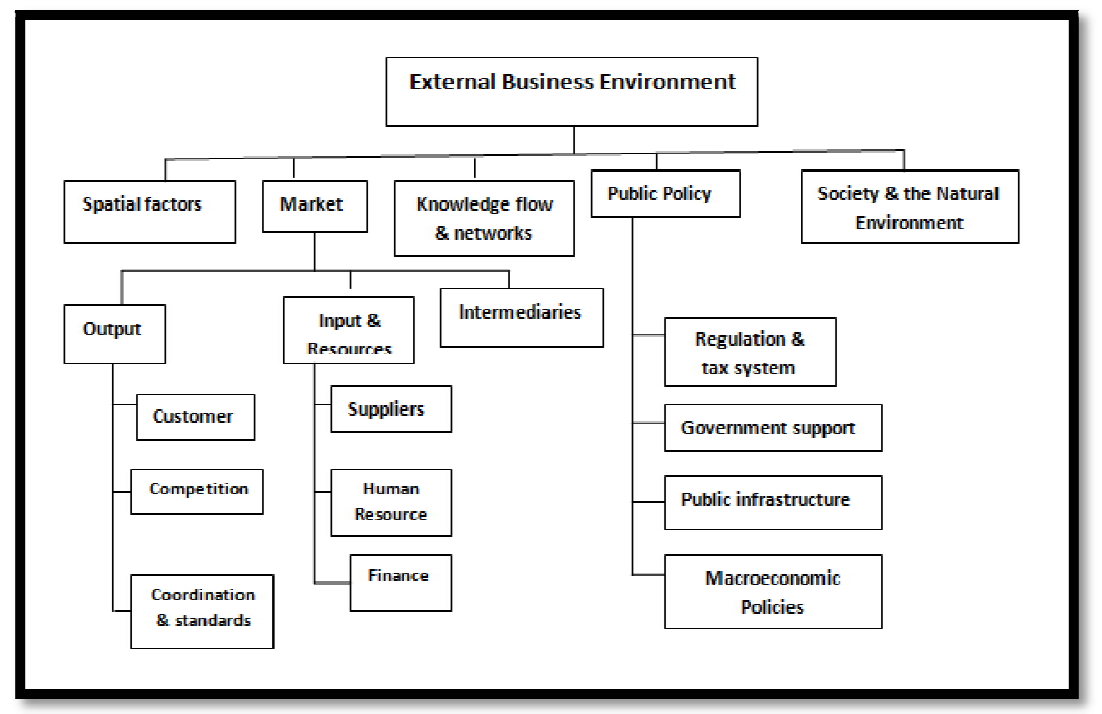

Figure 1: Element of External Environment for Business Innovation Source: Oslo manual, OECD/Eurostat (2018)

\subsection{Business Networks and Innovation}

Network activities are important element to firm innovation and hence, collaboration among firms has been recognized as important in supplementing the internal innovative activities of firms in recent times. Traditionally, the focus was to generate ideas within the organization. Nowadays, in open innovation models suggest firms search for masterminds from outside organization in addition to their own domain in order to enhance their innovation efforts (Chesbrough, 2003). Firms operate in networks and they form merger, alliance, strategic partnership and collaboration in their business network. Business network mainly refers to the direct and indirect relation of firms, or any business unit companies (Öberg C., 2019). Firms bring new technologies to product development, to add new feature for existing product and to the production of it as well as market penetration strategies from their business network (Mikhaylova, A., 2014).

Research and Development ( $R$ and D) are closely linked to innovation activities and firms may not self sufficient in their own R and D efforts. Hence, they may resort for collaboration with others. Innovative collaboration could be initiated 
from personal relationship and could promoted to geographical proximity (Keskin, S., 2011). Collaborations in R and D are important for risk sharing, exploitation of economies of scale and scope, reducing duplication of research efforts, access to complementary assets, and reduction of time to market (Jorde and Teece, 1990). Firms which are undertaking R\&D collaboration acquire new capabilities and improve their ability to monitor, absorb, and exploit external knowledge (Rosenberg, 1990). For large firms, international innovation collaboration is a possibility as it allows them to have access to build- up resource and knowledge; share possible risk; and chance to integrate to global value chains (OECD, 2016). Researchers such as Sharif, N. and Huang, C. (2012) establish evidence that in China firms with collaborative innovation activities are more likely to survive, while other researcher such as Wang C. et. al. (2015) and Cricelli, L. et al., (2016) argue that firms that connect their in-house $R \& D$ functions with external partners help them to enhance their innovation activities.

In fact, it is also recognized that innovative ideas could be initiated from employees, customers, suppliers, universities, and other groups of stakeholders (Drexler G., Janse B., 2013). Most significant sources are identified and rated in the order of their impact as follow: from employees, business partners, customers, consultants, competitors associations, trade shows, conference boards; internal sales and service units; internal research and development, and academia (Alexandra I. et al., 2018).

Social networks are also important channel information and also for innovation diffusion. Social networks have the potential to influence learning processes, provide opportunities for problem-solving, and establish new ideas (Kolleck, N. 2013).

However researchers such as Kolleck, N. and Bormann I. (2014) point out that the success of innovations essentially depends on types of trust. First, innovations are implemented when the network members responsible for implementing them trust in their efficacy. Second, innovations are diffused through social networks that are based on trust. The proper functional interaction in their business value chain accelerates new product development (Gonzalez-Z, et al. 2017).

Innovations are therefore relate to business networks as they result from interaction between business partners and or, the interaction patterns among various business actors, be fitted into current business networks. Innovation process is therefore can be seen as distinction between innovation and diffusion so that the creation of knowledge and its assimilation via networks are part of a single process.

Social network theory also suggests that a network ties that a firm maintains can provide informational advantages and facilitate information diffusion. The structure of inter firm network can influence the dynamics of information diffusion among firms and affect aspects of firm innovation (Chuluun T. et al, 2017).

Therefore, studies of social networks are essential not only for explaining the logic of interactions between individual actors, but also for understanding broader patterns of institutional learning, evolution of economic structures and creation of new technological knowledge (Keskin, S., 2011).

\section{Social Network Analysis in Innovation Research}

Recently, researchers from various fields have been using the Social network analysis (SNA) to study and analyze the possible ties among these actors. Social network research understands individuals within their social context, acknowledging the influence of relationships with others on one's behavior. Hence, social networks can promote innovation processes and expand opportunities for learning (Kolleck, N, 2013).

SNA is an interdisciplinary methodology developed mainly by sociologists and researchers in social psychology in the 1960s and 1970s, further developed in collaboration with mathematics, statistics, and computing that led to a rapid development of formal analyzing techniques which made it an attractive tool for other disciplines like economics, marketing or industrial engineering (Scott, J., 2000).

The four important concepts used in network analysis are network density, centrality, betweenness and centralization. There are also four measures of network performance: robustness, efficiency, effectiveness and diversity. A network is a set of nodes connected by a set of ties. The nodes could be persons/ individuals, teams, organization, concepts, patents, etc. (Coulon, F., 2005).

Social Network Analysis enables us to capture the interaction between actors and social context, to better understand how innovations are implemented and diffused, to analyze how and why social or educational change takes place or does not take place, and to disclose opportunities for future strategies.

SNA uses qualitative and quantitative techniques. Quantitative techniques of SNA enabled to identify innovation networks, to determine network boundaries, to define actors within the innovation network, and to investigate the network position of actors. A combination of qualitative and quantitative SNA techniques helps the fruitful for innovation research; and in order to better understand the role of social networks in the diffusion of social innovations (Kolleck, N. 2013).

Since data are required to show the network analysis of firms. Thus, social network analysis of practical firms is not shown here. However; below, innovation activities of firms and their performance are reviewed.

\section{Innovation and Firm Performance}

Innovation strategies, innovation activities and business network are important steps of firms to remain competitive by accessing knowledge and efficient utilization of resources from collaboration along business networks, besides they able to conquer market opportunities and challenges timely thereby ultimately improve their performance. A growing body of literatures assesses the impact of innovation on firm performance in terms of financial performance, customer performance, internal business processes performance and learning and growth performance (Karabulut, A. T., 2015) 
Moretti F. and Biancardi D. (2018) on their study that analyze the effects of open innovation on firm performance, they consider firm performance as: economic performance measured as the amount of firm turnover; firm financial performance measured with shares value; and human resources performance measured as the level of employment. As innovation could be product, process, marketing and organizational; and the effect also depend on which innovation is made. Evidences also document the impact of innovation on labor productivity. Those report a positive impact of technological innovation on labor productivity and firm performance such as (Gunday, G.et al, 2011; Karabulut, A. T., 2015; and Lööf and Heshmati, 2006; Tuan, N. et al., 2016).

Further, Jože P. D. et al (2011) combining information on firm-level innovation with accounting data of Slovenian firms, they found that innovation positively impacts productivity growth. Whereas Xiaolan Fu et al., (2018) find that innovation positively impacts the labor productivity of firms for Ghanaian manufacturing firms, and technological innovations more than managerial innovations. Moreover, according to Wadho, W. and Chaudhry, A. (2018), product innovation for Pakistani textile and apparel manufacturers leads to increased labor productivity.

On the other hand, Cefis, E. and Marsili, 0. (2006) examines the relationship between innovation and the survival probability of manufacturing firms in the Netherlands and they found small and young firms benefit from innovation to survive in the market in the long run. Whereas Dai X. et al. (2018) investigate innovation and exporting decisions on Chinese manufacturing firms and find out that starting to export alone negatively affects firm level markup and productivity whereas start to innovate alone has a considerable positive impact. They emphasize the complementarities between export and innovation in improving firms' performance. Besides, Caldera A. (2010) using Spanish manufacturing firms found a positive effect of firm innovation on the probability of participation in export markets, especially from product innovation.

Atalay, M., Anafarta, N. and Sarvan, F. (2013) examine the relation between innovation type and firm performance, for Turkish automotive supplier industry and they document a result that suggest product and process innovation has positive impact on firms performance.

Lee, R., et al. (2017) they show the synergetic effects of product, process, marketing, and organizational innovation and show the effect of a firm's strategic orientations, exploration and exploitation, on innovation activities in terms of process and product innovation. Further, moderating effect of marketing and organizational innovation differences between high-tech and low-tech industry. For high-tech firms, new product and firm performance is increased with marketing innovation and low-tech firms, process innovation positive impacts on a firm's performance with organizational innovation.

Guo B., Wang J, and Wei, S. (2018) using Chinese listed manufacturing firms, they examine the relation between firms R and D spending and their future performance. They point out that those firms with product differentiation strategy tend to spend more $\mathrm{R}$ and $\mathrm{D}$ and are better performer.

However, some other researchers such as Santos et al. (2013) examine the relationship between innovation and firms' performance in Brazil using a comprehensive database on innovation and financial information. They document the innovative effort of a company do not explain financial performance significantly.

Other group of researches document that open innovation is critical to superior performance. Moretti F. and Biancardi D. (2018) examine the effects of open innovation on firm performance and they found that the effect of internal development influences the economic performance for larger firms, and increases employment only for relatively smaller firms, while it has no effect on the financial side of performance. Similarly, Zhang S. et al. (2018) study the relation of human capital with open innovation and the financial performance of firms. On their results they demonstrate that there is an inverted U-shape relationship between open innovation and firm profitability. They also indicate the quality of human resource magnify the effect of open innovation.

\section{Conclusion}

In today's globalized business environment, world firms are facing fierce competition to sustain profitability in the market and meeting customers' needs. To respond effectively to the demanding global environment, firms need to develop a range of export capabilities by accessing new technologies, managerial practices, and technical and marketing skills and continuously upgrade them over time.

The main challenge facing firms is how to take advantage of new resources and markets and many firms over the world are under pressure and the pressure is affecting the entrepreneurial environment. Hence, Entrepreneurship has become increasingly important for innovations and economic development and innovation decisions are the key strategy for every firm; and firms may react in different ways to meet these challenges from global competition.

Innovations are therefore relate to business networks as they result from interaction between business partners and or, the interaction patterns among various business actors, be fitted into current business networks. Social network theory also suggests that a network ties that a firm maintains can provide informational advantages and facilitate information diffusion and as Social Network Analysis enables us to capture the interaction between actors and social context, to better understand how innovations are implemented and diffused. Recently, inter organizational collaboration has been recognized as important in supplementing the internal innovative activities of organizations. The use of social network analysis technique in innovation research is quite important.

\section{References}

i. Adner, R. and Feiler, D. (2019). Interdependence, Perception, and Investment Choices: An Experimental Approach to Decision Making in Innovation Ecosystems, 30(1) 1-234(online). https://doi.org/10.1287/orsc.2018.1242. 
ii. Adner, R. and Kapoor, R. (2016). Innovation ecosystems and the pace of substitution: Re-examining technology S-curves, Strategic Management Journal, 37(4), 625-648.

iii. Agapitova, N. (2005). The Role of Social Networks for National Innovation Systems' Dynamics, The World Bank, 1818 H St, NW Washington DC, 20433, USA.

iv. Atalay, M., Anafarta, N. and Sarvan, F. (2013). The relationship between innovation and firm performance: an empirical evidence from Turkish automotive supplier industry, Procedia -social and behavioral sciences 75, 226235.

v. Caldera, A. (2010). Innovation and exporting: evidence from Spanish manufacturing firms, Review of World Economy, 146:657-689, Springer.

vi. Chesbrough, HW (2003). Open Innovation: The New Imperative for Creating and Profiting from Technology. Boston, MA: Harvard Business School Press.

vii. Chuluun, T, Prevost A., and Upadhyay, A., (2017). Firm network structure and innovation, Journal of Corporate Finance.

viii. Coulon F., (2005). The use of Social Network Analysis in Innovation Research, A literature review Division of Innovation - LTH, Lund University, Sweden.

ix. Cricelli, L., Greco, M. \& Grimaldi, M. (2016). Assessing the Open Innovation Trends by means of the Eurostat Community Innovation Survey, International Journal of Innovation Management, Imperial College Press, 20(3), 1650039 (30 pages), DOI: 10.1142/S1363919616500390

x. Dai X., Sun, Z. and Liu, H. (2018). Disentangling the effects of endogenous export and innovation on the performance of Chinese manufacturing firms, China Economic Review, 50, $42-58$. https://doi.org/10.1016/j.chieco.2018.03.007

xi. Drexler G., Janse B. (2013). Social Network Analysis: An Important Tool for Innovation Management. In: Brem A., Viardot É. (eds), Evolution of Innovation Management, Palgrave Macmillan, London.

xii. Eggink, M. (2013). The components of an innovation system: A conceptual innovation system framework, journal of innovation and business best practices. DOI:10.5171/2013.768378.

xiii. Fischer, M. (1999). Network Activities of Manufacturing Firm, book chapter.

xiv. Gonzalez-Ziapatero, Gonzalez-Benito and Lanne-longue (2017). Understanding how the Functional Integration of Purchasing and Marketing Accelerates New Product Development, International Journal of Production Economics.

xv. Greenstone, M. and Looney, A. (2011). A Dozen Economic Facts about Innovation. Policy Memo. The Hamilton Project, Brookings.

xvi. Gunday G, Ulusoy G., Kilic, K. and L. Alpkan (2011). Effects of Innovation types on firm performance, International Journal of Production Economics, 133, 662-676.

xvii. Guo B., Wang J, and Wei, S. (2018). R and D Spending, Strategic Position and Firm Performance, Frontiers of Business Research in China 12(14).

xviii. Jorde T. M. and Teece, D. J. (1990). Innovation and Cooperation: Implication for Competition and Antitrust, Journal of Economic Perspective, 4 (3), 75-96.

xix. Jože P. Damijan, C` rt Kostevc, and Matija Rojec (2015). Innovation and Firms' Productivity Growth in Slovenia: Sensitivity of Results to Sectoral Heterogeneity and to Estimation Method, Book chapter.

xx. Karabulut, A. T. (2015). Effects of Innovation Types on Performance of Manufacturing Firms in Turkey, Procedia Social and Behavioral Sciences, 195, 1355 - 1364.

xxi. Karlsson, C. and Tavassoli, S. (2015). Innovation strategies and firm performance, Center of Excellence for Science and Innovation Studies (CESIS), electronic working paper series 401.

xxii. Keskin, S. (2011). International journal of business and management studies 3(1), ISSN. 1309-8047 (online).

xxiii. Kolleck N. (2013). Social network analysis in innovation research: using a mixed methods approach to analyze social innovations, Eur J Futures Res, 1:25 Springer.

xxiv. Kolleck N. and Bormann I. (2014). Analyzing trust in innovation networks: combining quantitative and qualitative techniques of Social Network Analysis, 17:9-27, Springer.

xxv. Lee, R., Lee, J.-Ho and Garrett, T. (2017). Synergy effects of innovation on firm performance, Journal of Business Research, 99, 507-515, https://doi.org/10.1016/j.jbusres.2017.08.032

xxvi. Lööf H. And A. Heshmati (2006). The Relationship between Innovation and Performance: A Sensitivity Analysis, Royal Institute of Technology, Industrial Economics and Management, the United Nations University, UNU/WIDER.

xxvii. Marshall, G. and Parrra, A. (2019). Innovation and competition: The role of the product market, International Journal of Industrial Organization, 65, 221-247 https://doi.org/10.1016/j.ijindorg.2019.04.001

xxviii. Moretti, F. and Biancardi, D. (2018). Inbound open innovation and firm performance: Journal of Innovation \& Knowledge. (http://creativecommons.org/licenses/by-nc-nd/4.0/).

xxix. Nham Tuan, Nguyen Nhan, Pham Giang, Nguyen Ngoc (2016). Journal of industrial Engineering and management, 9(2), 413-431. DOI: http://dx.doi.org/10.3926/jiem.1564.

xxx. Öberg C. (2019). The role of business networks for innovation, Journal of Innovation \& Knowledge. 4(2), 124-128 , https://doi.org/10.1016/j.jik.2017.10.001

xxxi. OECD (2007). Innovation and Growth: Rationale for an Innovation Strategy.

xxxii. OECD (2016). G20 Innovation Report 2016. 
xxxiii. OECD/Eurostat (2018). Oslo Manual 2018: Guidelines for collecting, Reporting and Using Data on Innovation, 4th Edition, the measurement of Scientific, Technological and Innovation Activities, OECD Publishing, Paris/ Eurostat, Luxembourg.

xxxiv. Pisano, G. (2015). Innovation: You Need an Innovation Strategy, Harvard Business Review.

xxxv. Porter, M. E (1990). The Competitive Advantage of Nations. Harvard Business Review.

xxxvi. Rosenberg (1990). Why do Firms do Basic Research (with their own money)?, Research Policy, 19,165-74.

xxxvii. Santos, D.F.L, Basso, L. F. C., Kimura, H., Kayo, E. K (2014). Innovation efforts and performances of Brazilian firms, Journal of Business Research, 67, 527-535.

xxxviii. Scott, J. (2000). Social Network Analysis: A Handbook, Sage publisher.

xxxix. Sharif, N. and Huang, C. (2012). Innovation strategy, firm survival and relocation: The case of Hong Kong-owned manufacturing in Guangdong Province, China, Research Policy Elsevier, 41(1), 69-78. https://doi.org/10.1016/j.respol.2011.06.003

xl. Wadho, W. and Chaudhry, A. (2018). Innovation and firm performance in developing countries: The case of Pakistani textile and apparel manufacturers, Elsevier, Research Policy, 47(7) 1283-1294. https://doi.org/10.1016/j.respol.2018.04.007.

xli. Wang, C. Chang C., George C. Shen (2015). The effect of inbound open innovation on firm performance: Evidence from high-tech industry, journal of Technological Forecasting \& Social Change, 99, 222-230.

xlii. Xiaoyong Dai, Zao Sun and Hang Liu (2018). Disentangling the effects of endogenous export and innovation on the performance of Chinese manufacturing firms, China Economic Review. https://doi.org/10.1016/j.chieco.2018.03.007.

xliii. Zhang, S., Yang, D., Qiu, S., Bao X. and Li, J. (2018). Open innovation and firm performance: Evidence from the Chinese mechanical manufacturing industry: Journal of Engineering and Technology Management. HTTPs://doi.org/10.1016/j.jengtecman.2018.04.004. 